\title{
The Development of Learning Material in Teaching Writing used Project Based Learning with Graphic Organizer Concept
}

\author{
Tri Wahyuni CHASANATUN ${ }^{1}$, Sri LESTARI ${ }^{2}$ \\ Primary Education Department \\ Faculty of Teacher Training and Education, FKIP \\ Madiun, Indonesia \\ uniechasa@gmail.com ${ }^{1}$, lestarisri@unipma.ac.id²
}

\begin{abstract}
Based on previous research about using graphic organizer in teaching writing, the result showed that it helps students to explore students' ideas in writing, especially in prewriting process. By using graphic organizer, students were easier in preparing paragraphs and defining content of their paragraph.This research is aimed to develop a learning material (module) used Project Based Learning with graphic organizer concept in Paragraph writing class. The design of this research was a research and development design developed by Dick and Carey, and the subject was second semester students of English Department Universitas PGRI Madiun. The results of this research was by using this book, it can help students improve writing competence. This module is a guide for students in learning paragraph writing.
\end{abstract}

Keywords-paragraph writing, module, project based learning, graphic organizer concept

\section{INTRODUCTION}

One of abilities that must be mastered by the students of English Teaching Department is writing. The course of writing in English Teaching Department, University PGRI Madiun starts from semesters one to four where tiered course material is taught. The first semester students are taught about the sentences building. Furthermore, in the second semester students are taught to write various kinds of paragraphs and introduction of types of texts. Then in the third semester, students gain knowledge of various types of essays and how to write a coherent essay. Finally, in semester four students try to write articles. In writing class students are expected to master basic writing competencies, namely: proper organizational arrangement, coherent content, grammar selection or appropriate language arrangement, appropriate vocabulary selection, and appropriate mechanical or punctuation usage.

In Paragraph writing class, students are expected to write different types of paragraphs and essays, making articles in accordance with international rules and this will be useful when they write their final task, which called as thesis. Efforts to improve the quality of students' writing have been carried out by the Writing Teaching Team, by selecting appropriate methods and media usage in teaching. Related to this, it needs a learning module that intensively provides writing guides that contains of various paragraphs. It is hoped that by doing such kind of efforts, the improvement on the teaching learning process on Writing class will be Achieved.

Related to the importance of learning resources in the learning process, researchers are focused more deeply and try to solve problems related to learning resources. As stated by Suratno (2008) Learning resources are good sources of data, people, and certain forms that students can use in learning, either separately or combined so as to facilitate students in achieving learning objectives. Added, learning resources are narrowly directed at printed materials

One of the learning resources is the module. Modules are designed specifically to assist students in improving learning outcomes and foster student motivation in learning. The selection of content concepts and teaching strategies in the module in which there is the concept of Project Based Learning and varied graphic organizer media can increase the willingness of students to write and make it easier for them to produce quality writing. Menurut Gregory dan Carolyn (2007: 101) Graphic organizer is a medium used to compile information and let students understand what they are thinking. This statements also supported by Hibbard and Elizabeth (2003: 117), stated that "A diagram that represents a direct relationship by the thinking ability of a verb." Sousa (2005: 192) added that "Graphic organizer is a useful medium for composing and representing knowledge and also to describe the relationship of a concept.

According to Nik et al.(2010: 1$)$ to be an effective writer we need a great deal of skills like writing readiness and grammatical rules. Tessema (2005) also points the difficulty of writing is also caused by the requirements of the knowledge of grammar and vocabulary and clear organized presentation of ideas. He further explains that because of the difficulty, pupils tend to have lack of the motivation for learning writing. Olshtain in Celce-Murcia (2001:207) defines writing as an act 
of communication which takes place between the writer and the reader via the text in an interactive process.

Based on the theory above, we can conclude that to be a good writer we need to read a lot of information, learn about grammar, and vocabulary. It happens because in delivering the writing, we as a writer transfer information because writing is an act of communication.

One tool that has been shown to be effective for structuring written discourse is graphic organizers (Ellis \& Howard, 2005). Graphic organizers (GO charts) are visual and spatial displays of information that graph the logical relationships between the key concepts, facts, terms, or ideas from the learning task (DiCecco\& Gleason, 2002). Key concepts, usually single words or phrases, are arranged logically on the GO chart with lines, arrows, and spatial representations clearly highlighting interrelationships and providing a structured way to see a picture of the information. GO charts are designed to extract salient information and eliminate extraneous information (i.e., the information that frequently distracts learning disabled students). They provide a foundation for an explicit, organized way of visually expressing the relationship between new and existing knowledge and profiling the connections between them (Ellis \& Howard, 2005; Kim, Vaughn, Wanzek, \& Wei, 2004).

Also referred to as semantic maps, cognitive maps, advance organizers, or concept diagrams, GO charts can be completed in many different formats such as cause and effect diagrams, compare and contrast diagrams, sequence charts, and main idea and detail charts (Baxendell, 2003). Wellstructured GO charts can be used flexibly to represent multiple goals. For example, the cause and effect diagram aids students in visualizing the relationship between a single cause and a single effect, or the focus can be on a single main event and its primary causes and effects. This format allows students to organize thoughts before writing by displaying abstract relationships in a graphic representation where the relationships are clearly displayed (Kim et al., 2004).

A different presentation of complex relationships is displayed in compare and contrast diagrams which visually depict the similarities and differences across main ideas. This format can be used to present one main idea with its supporting details along one strand in the diagram which is then contrasted with the opposing main idea, or the ideas can be compared and contrasted point bypoint across main ideas (Baxendell, 2003). Sequence charts are used to illustrate a series of events. They flow in one direction, either right to left or top to bottom, and are often connected by arrows and numbered boxes to ensure clear understanding of the relationships of the sequence of events. This format is beneficial to learning disabled students in the writing process since it visually organizes important events sequentially (Ellis \& Howard, 2005).

Another challenge faced by learning disabled students is difficulty conceptualizing and differentiating main ideas from details. The main idea and detail chart helps to extract main ideas and supporting details from extraneous information, allowing the focus to remain on relevant information (Ellis \& Howard, 2005). Students can use this format in the writing process to create paragraphs that focus on one main idea and details highlighting the importance of the main ideal.

Project-Based Learning (PBL) has been described as an innovative approach to learning that teaches a multitude of strategies critical for success in the 21 st century compared to the traditional model (Bell, 2010; Barron \& DarlingHammond, 2008; Blumenfeld et al, 1991; D’Orio, 2012). According to Bell (2010) and David (2008), PBL incorporates a student- driven, teacher facilitated approach to learning where learners pursue knowledge by asking questions that trigger their curiosity. In addition, inquiry creates the framework of a project. Primarily, students develop a question and are guided through the research under the teacher's supervision. Further, discoveries are created through projects and shared with a select audience. By design, student choice serves as the key element of this approach (Bell, 2010; Thomas, 2000; 35 Blumenfeld et al, 1991).

According to Harris and Katz (2001), the PBL instructional method centers on the learner. Project-Based Learning serves as a comprehensive approach to classroom teaching and learning that is designed to engage students in investigation of complex, authentic problems and carefully designed products and tasks (Blumenfeld, et at., 1991; Bell, 2010; Barron \& Darling-Hammond, 2008; MaKinster et al, 2001). In addition, PBL created opportunities for groups of students to investigate meaningful questions that required them to gather information and 36 thinkcritically. Overall, David (2008) emphasized the core idea of PBL is that real world problems capture students' interest and provokes critical thinking as the students gain and apply new knowledge through problem-solving.

\section{METHOD}

This research done in Paragraph Writing Class of English Department Universitas PGRI Madiun in AprilAugust 2017. This research is aimed to develop a modul of paragraph writing using Project Based Learning with graphic organizer concept. The source of data was researcher as informant. Data of moduls' quality from students and lecturer response and product validation from experts.The design of this research was research and development using Borg and Gall design. The implementation of research procedure as follow:

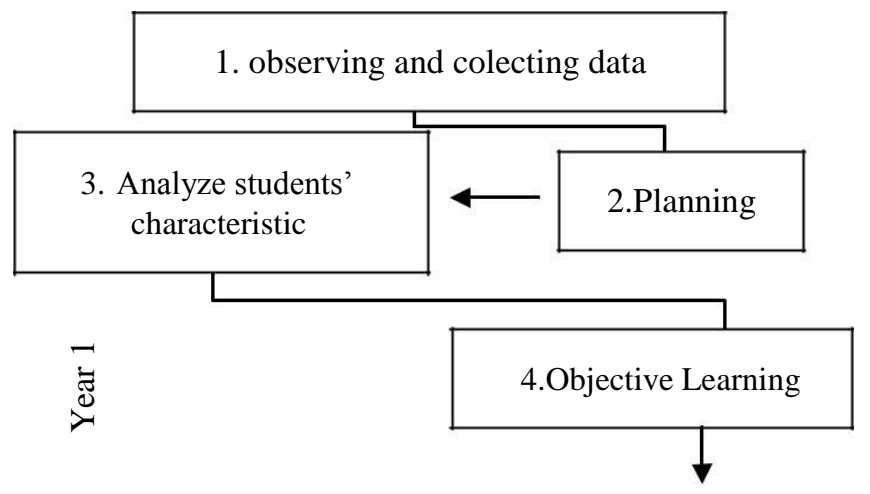




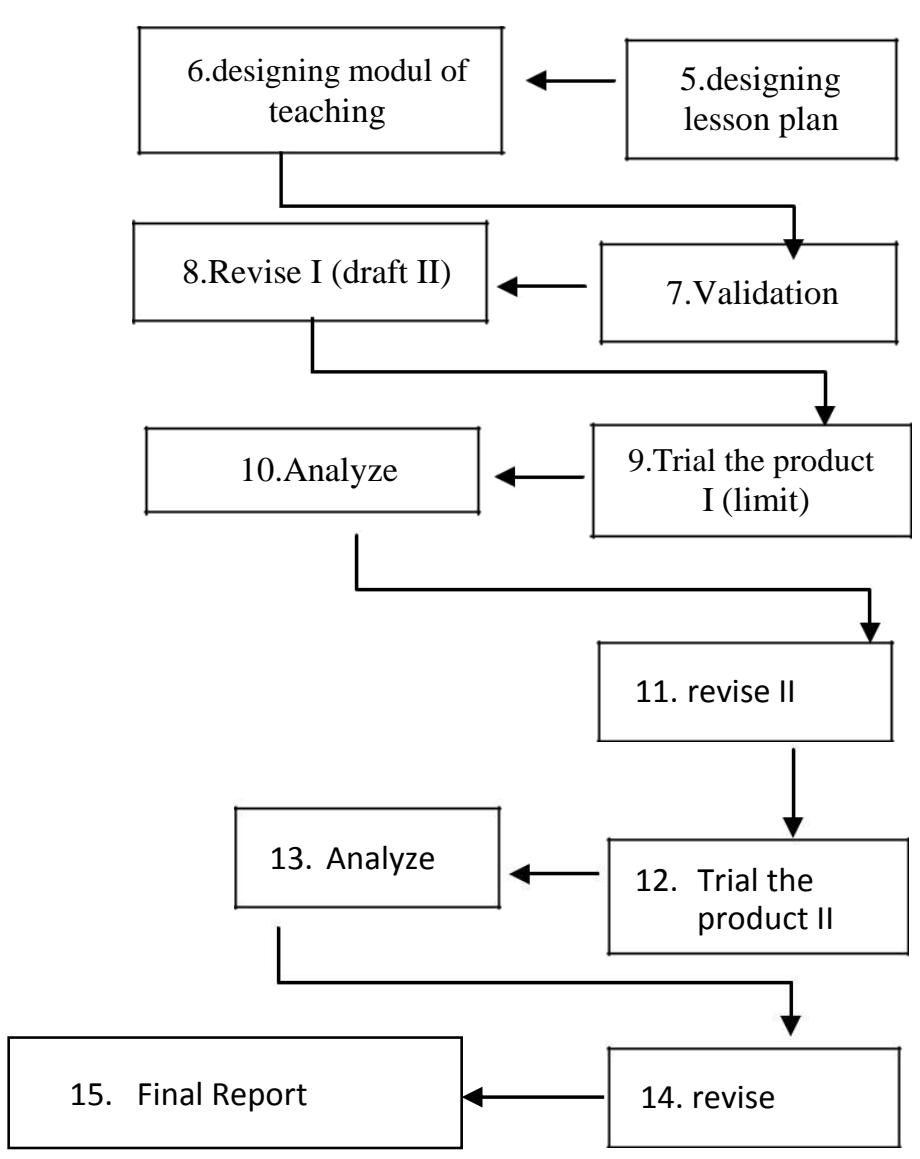

Fig. 1. Diagram of designing paragraph writing module use Project Based Learning with Graphic Organizer Concept

The technique of retrieval data as folows:

1. Documentation technique

2. Product validity from indirect observation technique In analyzing the data are as follows:

1. Analyze the module design of paragraph writing use Project based Learning with Graphic Organizer Concept. Then revised and tryout the product. Here the formula

a. Product Validity

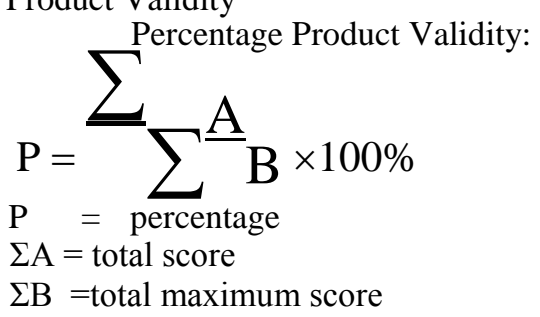

\section{RESULT AND DISCUSSION}

The process in this research were; Identification of learning objectives, learning analysis, student character analysis, formulation of learning objectives, RPP development, development of teaching materials module, product validation, revision 1 , field trials, analysis, revision 2, trial 2, analysis, final revision.

The development process in this study was conducted from April to August 2017, with details of implementation time in Table 4.1. The process of development that has been implemented in this research is: (1) the collection of initial information from observation process in class, (2) development planning by recording problems and composing textbooks and try out, (3) the development of product draft that is learning module paragraph writing Which is submitted to the validator, the validator of the writing course, (4) the initial testproduce data result of interview, observation, and questionnaire then analyzed. Initial test is addressed to 2 classes ie 2A that is 10 students (5) Further product revision done after carrying out initial test. The results of these trials obtained qualitative information about the products developed. (6) Field trials produce quantitative data from learning outcomes. The field try out was tested to 15 students of class 2A, (7) Product Revision was done based on field tryout, this was done to improve product, (8) Field test involving research subject by (interview, observation, questionnaire and analysis. This field test was piloted to 32 students of class $2 \mathrm{~A}$ with different students in the previous test (9) The final product revision was performed after the field test.

\section{Collecting Data}

Preliminary research and information collection includes classroom observation or observation. In Paragraph Writing Class, students begin to learn about writing paragraphs. At the beginning of the lecturers' meeting taught about the part of the paragraph, the order of the paragraph, and how to create a good quality paragraph. At the first meeting until the third meeting, the new students get the theory about making paragraph which at the end of the meeting students do the exercise questions. Subsequently at the next meeting, students begin to make paragraphs begin with a description paragraph. After the obeservation in class $2 \mathrm{~A}$, the number of students 31, obtained some data related to the results of writing the paragraph of students, namely: 15 students still have difficulties in preparing a paragraph of unity and coherent (organization) 16 students writing content is still less good (content) 12 students are still writing By using punctuation, vocabulary and mechanics, 14 students are constrained in the grammar. Broadcast the observation, it was found that there are only 4 students who have good writing paragraph skill. With these preliminary observations, researchers get data about things that make students feel difficult to write.

\section{Planning}

The planning stage was carried out based on the previous observation stage. From the observation data, it was found that most of students still find difficulties inwriting good quality paragraphs, with indicator: the preparation of the appropriate writing organization, the content, the use of punctuation, proper spelling, appropriate vocabulary selection, and the preparation of sentence or grammar right. There are times when students have organized paragraphs, but have 
problems with the correct or incorrect vocabulary selection in spelling and punctuation. There were also students who write with good content, but still have problems with grammar selection, and vice versa. Problems in the organization because students were still difficult in making topic sentence, supporting sentence and concluding sentence appropriate. Then on the issue of content, this is caused because the students still discuss simple topic in the. It could be due to lack of interest in reading students. Next to the problem of grammar, vocab, and mechanics, needed accuracy and proofreading back before the task is collected. In this planning stage, the lecturers carry out the pretest. There are 12 students got the value of 70 and above (B), the rest is still below 70, this class is used as research subjects.

\section{Development of (Learning Module) danResult of Field Try out Product}

Development of the initial production format, in this case is the creation of learning modules paragraph writing based direct instruction with the concept of grapicorganizer, and validate the learning module to the validator. The result of the assessment of the development process of learning module paragraph writing based on direct instruction with the concept of graphic organizer, validator learning writing, is as follows:

\begin{tabular}{|c|c|c|c|c|}
\hline & \multicolumn{2}{|c|}{ Form Draft 1} & \multicolumn{2}{|c|}{$\begin{array}{l}\text { Revise edition after } \\
\text { tryout } 1\end{array}$} \\
\hline & \multicolumn{2}{|l|}{ Validator } & Validator & \\
\hline & $\begin{array}{l}\text { Experts } \\
\text { in } \\
\text { Writing }\end{array}$ & lecturer & $\begin{array}{l}\text { Experts in } \\
\text { writing }\end{array}$ & Lecturer \\
\hline Validation & 62 & 64 & 72 & 77 \\
\hline $\begin{array}{l}\text { Assesment } \\
\text { aspect }\end{array}$ & 22 & 22 & 22 & 22 \\
\hline $\begin{array}{l}\text { Highest } \\
\text { score }\end{array}$ & 88 & 88 & 88 & 88 \\
\hline $\begin{array}{l}\text { Analyze } \\
\text { thedata } \\
\text { percentage }\end{array}$ & $70.45 \%$ & $72.72 \%$ & $81.81 \%$ & $87.5 \%$ \\
\hline
\end{tabular}

Fig. 2. Validation data of form draft 1 and result of revision edition

The data Analysisof draft 1 Module Validation from Students

$$
\begin{aligned}
P & =\frac{\text { Total Assesment score }}{\text { Total Highest Score }} \quad \times 100 \% \\
& =\frac{62}{88} \quad \mathrm{x} 100 \% \\
& =70.45 \%
\end{aligned}
$$

Based on Table 4.2, it is known that the validation of the initial production development of paragraph writing instruction module based on direct instruction from the writing learning expert, is considered in good category and worth to be tested because the presentation is $\geq 61 \%$. Furthermore, to get perfection, then made a revision based on suggestions and comments from each validator, for example: clarified section subheading, composition of the form more varied, layout design, and additional material for beberepa paragraph

\section{Initial tryout of Product}

Initial tryout resulted in interview data of students, observation by observers, and student questionnaires collected and analyzed. Initial test was tested to 10 students of $2 \mathrm{~A}$ semester.

The results of interviews to students are divided into three, namely (1) things favored by students from learning writing using paragraph writing modules use project based Learning with graphic organizer concept, the result were: writing guides quite clear, especially as a beginner, the material order is very easy to understand, the practice questions are varied and numerous, the graphic organizer design helps in writing especially in prewriting stages. (2) the unlikely thing of the module is, the design is still less interesting, there are some wrong words and the letters model needs to be fixed, in one paragraph the part of the exercise is still lacking (3) the suggestion for the module is to check the module and editing and revising incorrect parts, packed with attractive modules (external display and module design).

At the observation session, students are interested in studying and enthusiastic when given the exercise problem to write. Students also respond positively with the paragraph writing module where the explanation of each chapter and the exercises in it is very help them in writing.

From the results of observation can be concluded that learning paragraph writing using modul paragraph writing based project based learning with graphic organizer concept helped students in writing paragraph. The results of the questionnaire provide a positive response, one of which is the opinion of Anin Budi Cahyani, that the module is very helpful for students to write, esecially for beginner is because the module is easy to understand and many exercises on each unit. Another opinion from RiswandaArdanSetiawanstated that this module can help in getting started to write. Because it is a matter of getting started, and in this module many graphic organizer designs can be applied to start writing.

After interviews, observations, and questionnaires, proving that the book is worthy of trial, but there are still shortcomings, especially in the design and layout of writing.

\section{Field Try Out Product}

This field try out of product produce quantitative data; learning outcomes in paragraph writing courses. The quality writing of student paragraph writing based on criteria of writing on Brown (2004: 224-245). This test is tested on 15 students in class $2 \mathrm{~A}$. The results of the student scores are as follows:

A. Category Percentage of and Average Score of Students Field Test Stage

The percentage of each student score category is calculated to know what percentage of students get a certain score, so that later can be known the result of learning paragraph writing withproject based learning module with 
graphic organizer concept. To obtain a percentage of each value category is calculated by dividing the frequency of thestudents scoreof each category by the total number of students multiplied by one hundred percent.

Fig. 3. Students Score using Paragraph Writing Module

\begin{tabular}{|l|l|l|l|l|}
\hline $\begin{array}{l}\text { Class } \\
\text { Limit }\end{array}$ & $\begin{array}{l}\text { Class } \\
\text { Boundaries }\end{array}$ & $\begin{array}{l}\text { Midpoint } \\
(\mathbf{X i})\end{array}$ & $\mathbf{F}$ & $\mathbf{\%}$ \\
\hline $62-67$ & $61.5-67.5$ & 64.5 & 1 & 6.667 \\
\hline $68-73$ & $67.5-73.5$ & 70.5 & 2 & 13.333 \\
\hline $74-79$ & $73.5-79.5$ & 76.5 & 4 & 26.667 \\
\hline $80-85$ & $79.5-85.5$ & 82.5 & 4 & 26.667 \\
\hline $86-91$ & $85.5-91.5$ & 88.5 & 4 & 26.667 \\
\hline$\sum$ & & & 15 & 100 \\
\hline mean & 79.70 & & & \\
\hline mode & 83.85 & & & \\
\hline median & 83.23 & 7.48 &
\end{tabular}

Based on the tabel, it can be concluded that using this modul can help students in getting good score.

\section{Field Test}

On the field test the resulting data are interviews with students, observations in classroom, and questionnaires. Field test was tested to 31 students of 2 nd semester.The results of interviews with students can be seen that they like to learn paragraph writing withthis module. It helped them in writing especialy in prewriting and organizing stage. However, there was still a lack of module; in the module design was still less than perfect.Observation results din the classroom run succesfully. Students followed the lecture of paragraph writing with passion. The existence of graphic concept, helped them in the process of writing. Lecturers also were helped by the module because when she explained the material, then after that the students can practice in accordance with the existing module. Students were enthusiastic to write because on each different paragraph types they will try different graphic designs at the prewriting stage.

Furthermore, in the submission of questionnaires, students gave a positive response. Students like the module because each unit of content is clear, the exercises can help them in writing, with helpful examples.

From the result of the field test, the learning module still needs improvement before it is given to the students widely. Thus, after being revised, the book is worthy of being used as a learning paragraph writing module for semester 2 students.

\section{CONCLUSION}

Based on the research, it can be concluded that in developing paragraph writing modul follow some steps:

Identification of learning objectives, learning analysis, student character analysis, formulation of learning objectives, RPP development, development of teaching materials module, product validation, revision 1 , field trials, analysis, revision 2 , trial 2, analysis, final revision, and dissemination. After students and lecturer used this module, they gave positive response. They did like using this module because each unit of content is clear, the exercises can help them in writing, with helpful examples.

From the result of the field test, the learning module still needs improvement before it is given to the students widely. Thus, after being revised, the book is worthy of being used as a learning paragraph writing module for semester 2 students.

\section{REFERENCES}

[1] Bell, S. (2010). Project-based learning for the 21st century: Skills for the future. The

[2] Clearing House, 83, 39-43.Barron B., \& DarlingHammond, L., (2008). Teaching for meaningful learning.

[3] Baxendell, B.W. (2003). Consistent, coherent, creative the 3 c's of graphic organizers. Teaching Exceptional Children, Jan/Feb, 46-53.

[4] Blumenfeld, P. C., Soloway, E., Marx, R., W., Krajcik, J. S., Guzdial, M. et al. (1991). Motivating project-based learning: Sustaining the doing, supporting the learning.

[4] Cervetti, \& J. Tilson, Powerful learning: What we know about teaching for Understanding, San Francisco: Jossey-Bass.

[5] David, J. (2008, February). Project-based learning for the 21st century: Skills for the future. Educational Leadership, 65(5), 80-82.

[6] DiCecco V.M., \& Gleason, M.M. (2002). Using graphic organizers to attain relational knowledge from expository text. Journal of Learning Disabilities, 35(4), 306-320.

[7] Ellis, E., \& Howard, P. (2005). Graphic organizers: Power tools for teaching students with learning disabilities. Graphic Organizers and Learning Disabilities 1, 1-5.

[8] Harris, J. H., \& Katz, L. G. (2001). Young investigators: The project approach in early years.

[9] Kim, A., Vaughn, S., Wanzek, J., \& Wei, S. (2004). Graphic organizers and their effects on the reading comprehension of students with LD: a synthesis of research. Journal of Learning Disabilities, 37(2), 105118.

[10] Oshima, A., Hogue, A. 2007. Introduction to academic writing. White plains, NY : Pearson : Longman

[11] Richards. J. C. \& Schmidt. 2010. Second Language Writing. Cambridge University Press 